\title{
Belgrave Square in the 19th century
}

\author{
Margaret Harcourt Williams
}

The district of London known today as Belgravia was developed in the 1820 s. Previously it was called the Five Fields and was a rural area between Westminster and the village of Knightsbridge. Hay, herbs and vegetables are said to have been grown here and it was considered a difficult and dangerous area to cross on the journey to the west of London.

In the early 19th century the landowners, the Grosvenor family, Dukes of Westminster, began developing the area. This was a time of expansion for London and the builder of Belgrave Square, Thomas Cubitt, is said to have done "more to change the face of London than any other man".

Belgrave Square was laid out in 1826. The development was a success from the start, and a royal seal of approval was achieved when Queen Victoria rented number 36 for her mother. Over the years many of the houses have been lived in by eminent or titled families.

The south-west terrace, which includes number 17, was built in the early 1830s. The first tenant of number 17 was Sir Ralph Howard, a grandson of the Earl of Wicklow, a Whig MP for Wicklow and a member of the Athenaeum. In the 1841 census he was living here with his wife, seven female servants and four male servants. On the night of the 1851 census, he was away and only a housekeeper, butler and servant are recorded at number 17 . He was still living here in 1861 but the census records for that year are missing.

The next tenant was Pandeli Ralli, a Greek born in Marseilles who spent much of his life in London. He too was an MP, a Liberal who represented Bridport and then Wallingford. His household in 1871 consisted of his mother and sister, a domestic companion, a butler, two footmen, three lady's maids, a cook, a house maid, and a kitchen maid. His mother was not present in 1881 so there was only one lady's maid but there was an extra footman, another house maid and a scullery maid. Pandeli Ralli was away when the 1891 census was taken and the long-standing companion, now described as a housekeeper, three house maids, a cook, a kitchen maid and a hall boy were left in charge of the property.
It is likely that the household also included a coachman living with his family in the mews behind the Square but, as one census enumerator put it "this mews is most stupidly numbered" so it is difficult to identify which coachman served number 17 .

The Austrian Embassy, which is still the College's neighbour in number 18 , was there by

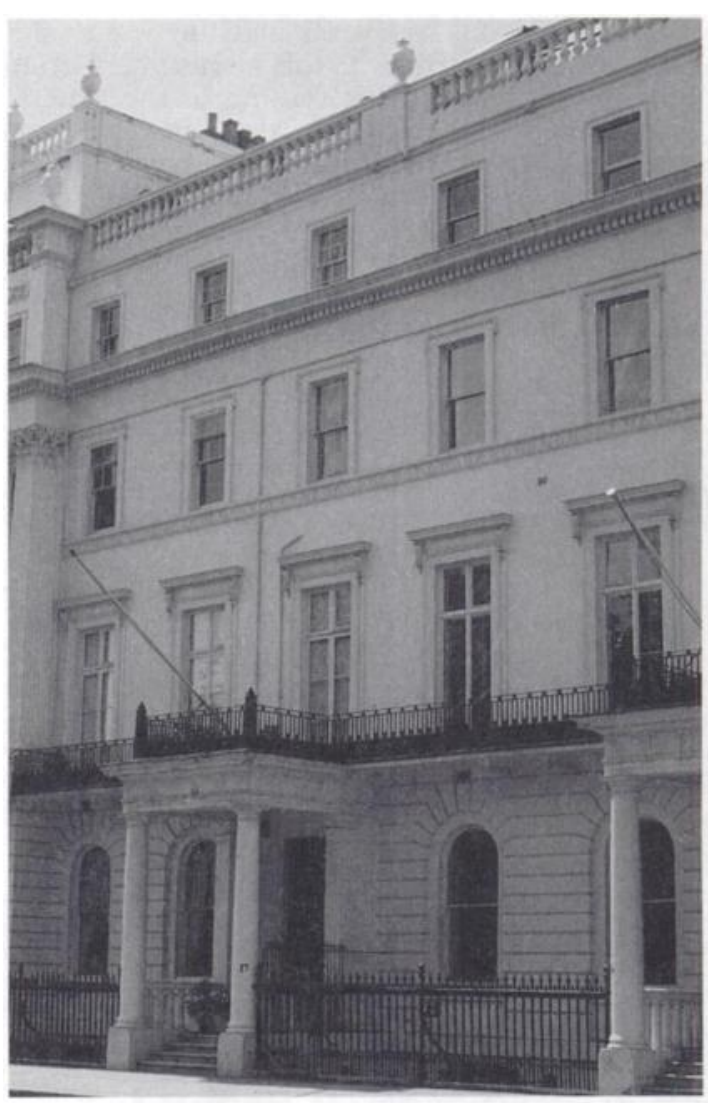

Fig. 1. The Royal College of Psychiatrists, 17 Belgrave Square, 1998. (Reproduced by kind permission of Belgrave and Portman Photography) 
1871. The Ambassador, who was a Count and the representative of what was then the vast Austro-Hungarian Empire, lived there with his Countess, a councillor, the Countess's companion and 15 servants. By 1891 there was a different ambassador and the number of servants had risen to 26 , including a governess, tutor and schoolroom maid for the Ambassador's three young children.

Number 16, the house adjoining the College on the other side, "became a meeting place for workers of science with those otherwise distinguished" when it was lived in for many years by Sir Roderick Impey Murchison, the famous geologist and geographer and "a man of indomitable energy and great powers of work" (19th century Dictionary of National Biography).

In the 19th century the rooms on the ground and first floors that are now the council, dining and members rooms and the library would have been the reception, drawing and dining rooms.
Family bedrooms were on the second floor, the domestic staff slept in the attics and the basement was for cooking and laundry; there would probably have been a water supply and a sewage system from the time the property was built.

The College came to Belgrave Square in 1974 and today number 17 is one of the few properties occupied by a single tenant.

These notes are based on information in census records 1841-91, excluding 1861, Directories of London, 19th century Dictionary of National Biography, Who's Who of British Members of Parliament, Vol. 1, 1832-85 by Michael Stenton and Belgrave Square 1827-1852 by William Carey.

Margaret Harcourt Williams, College Archivist, Royal College of Psychiatrists, 17 Belgrave Square, London SWIX 8PG

\section{Antisocial Personality Disorder: An Epidemiological Perspective}

\section{by Paul Moran}

Antisocial Personality Disorder is a controversial diagnostic category introduced by DSM-III in 1980. Its usefulness as a concept to clinicians and researchers is contentious and an extensive literature on the subject has accumulated. This book provides a comprehensive review and evaluation of the published epidemiological literature on antisocial personality disorder and diagnostic equivalents: dissocial personality disorder, psychopathy and sociopathy. It opens with a discussion of the central problems associated with assessing and classifying personality disorders and then focuses more specifically on the epidemiology of antisocial personality disorder. It will be a valuable source of reference to all those who are interested in antisocial personality disorder, whether from a research, clinical or management perspective.

December 1998, stba, 144pp, ISBN 1901242242

Avallable from Book Sales, Royal College of Psychiatrists, 17 Belgrave Square, London SWIX 8PG Tel +44 (0) 1712352351 (ertension 140), Fex +44 (0) 1712451231

The latest information on College publications is available on the Internet at www.rcpoych.ac.uk 